\title{
Effect of Cetiedil, an In Vitro Antisickling Agent, on Erythrocyte Membrane Cation Permeability
}

\author{
LeE R. Berkowitz and Eugene P. ORRINGer, Division of Hematology/Oncology, \\ Departments of Medicine and Hospital Laboratories, University of North Carolina \\ School of Medicine, Chapel Hill, North Carolina 27514
}

\begin{abstract}
A B S T R A C T Cetiedil has been reported to relieve painful crises in sickle cell anemia and to have antisickling properties in vitro. The drug alters neither oxygen affinity nor the solubility of deoxyhemoglobin S. Because the viscosity of the erythrocyte interior and the kinetics of gelation are dependent on the concentration of hemoglobin, we postulated that cetiedil might inhibit sickling by modifying erythrocyte sodium or potassium movements in a manner that would increase cell water content and thus dilute the cell hemoglobin. The drug has two such effects: it inhibits the specific increase in potassium permeability that follows a rise in cytoplasmic calcium concentration and it causes a rise in passive sodium movements. These effects are further evidence that cell ion and water movements may be important in the process of sickling and suggest a mechanism for the results reported with cetiedil.
\end{abstract}

\section{INTRODUCTION}

Cetiedil, one of a family of compounds synthesized as smooth muscle relaxants, relieves pain from claudication and Raynaud's phenomenon (1). In addition, cetiedil has been reported to decrease the duration and intensity of sickle cell crises, although this study was not performed in a controlled, double-blinded fashion (2). This effect may be more than vascular since a statistically significant decrease in sickle forms has also been observed when hemoglobin S-containing erythrocytes are deoxygenated in the presence of cetiedil $(1,3)$. Concentrations of cetiedil used in these in vitro studies were comparable to those achieved during in vivo administration (1). As the action of the drug differs from other antisickling agents, affecting neither the solubility nor the oxygen affinity of hemoglobin S (3), we postulated that cetiedil might exert

A portion of this work has been published in abstract form (1980. Clin. Res. 28: 823a; 1981. Clin. Res. 29: 330a).

Address reprints requests to Dr. Lee R. Berkowitz.

Received for publication 6 May 1981 and in revised form 3 July 1981. its beneficial effect by lowering the concentration of hemoglobin $\mathrm{S}$ within the erythrocyte.

The viscosity of the erythrocyte interior is largely a function of hemoglobin concentration. Thus, a fall in cell water content impairs erythrocyte deformability (4). This effect is magnified in the deoxygenated sickle erythrocyte because a rise in cell hemoglobin concentration greatly accelerates the rate at which hemoglobin $S$ polymerizes (5). There are also several lines of evidence to suggest that the sickle erythrocyte becomes dehydrated in the process of deoxygenation (6-9). Finally, in vitro and in vivo evidence indicate that hypotonic conditions, by lowering intracellular hemoglobin $S$ concentration, inhibit the tendency to sickle $(10,11)$. For these reasons a drug that increased sodium permeability or inhibited a preexistent tendency for potassium loss would, by preventing cellular dehydration, preserve the deformability of the sickle erythrocyte.

The present studies were designed to test the in vitro effect of cetiedil on ion and water movements across the membranes of normal and sickle erythrocytes. Two effects were found. Passive $\mathrm{Na}$ permeability, examined by both net and unidirectional flux studies, is increased. A preexistent tendency for $\mathrm{K}$ loss, studied by exposing erythrocytes to conditions known to generate a selective increase in $\mathrm{K}$ permeability, ATP depletion followed by Ca exposure (12), is inhibited by cetiedil. These properties that prevent cellular dehydration offer a potential explanation for the reported antisickling effects of cetiedil.

\section{METHODS}

Blood from hematologically normal volunteers or patients with sickle cell anemia who had not been transfused for a minimum of 6 mo was drawn into heparin-rinsed syringes and used within $30 \mathrm{~min}$ of collection. For experiments evaluating the net flux of $\mathrm{Na}$ and $\mathrm{K}$, the plasma and buffy coat were discarded and the remaining cells were washed four times at $10,000 \mathrm{~g}$ in $10 \mathrm{vol}$ of a $\mathrm{Na}$ wash containing, $\mathrm{NaCl} 155 \mathrm{mM}$; Hepes $5 \mathrm{mM}$; pH 7.4 at $37^{\circ} \mathrm{C}$. A small aliquot of these cells was 
reserved for the base-line measurement of $\mathrm{Na}, \mathrm{K}$, and water (the " 0 time" sample) and the remaining cells were suspended in buffered saline solutions, the composition of which are detailed in the figure legends. For $\mathrm{Na}, \mathrm{K}$, and water determination, the washed cells were centrifuged at $40,000 \mathrm{~g}$ in specially constructed lucite cell water tubes with a narrow well at the bottom for collection of the cell button. $\mathrm{Na}$ and $\mathrm{K}$ measurements were performed by flame photometry, on packed, weighed aliquots of the cells. Results were expressed as milliequivalents per kilogram of dry cell solid. The water content was measured by drying a known weight of wet cells to constant weight at $90^{\circ} \mathrm{C}$. Details of these procedures have been previously published (13).

All incubations were carried out at $37^{\circ} \mathrm{C}$ in stoppered flasks under air in a water-bath shaker set at 100 oscillations/ min over a traverse of $1 \mathrm{in}$. At the timepoints indicated on the figures, an aliquot of each suspension was removed and centrifuged at $10 ; 000 \mathrm{~g}$. Following removal of the supernatant by aspiration, the cells were washed four times in the $\mathrm{Na}$ wash solution and then processed for $\mathrm{Na}, \mathrm{K}$, and water content.

The unidirectional movement of $\mathrm{Na}$ was evaluated using ${ }^{22} \mathrm{Na} .{ }^{22} \mathrm{Na}$ was obtained as ${ }^{22} \mathrm{NaCl}$ from New England Nuclear, Boston, Mass. The cells were washed four times in $10 \mathrm{vol}$ of $\mathrm{Na}$ wash as described above and added to the appropriate solutions. After a 5 -min equilibration period at $37^{\circ} \mathrm{C}$, ${ }^{22} \mathrm{Na}$ was added in concentration sufficient to give $50,000 \mathrm{dpm}$. At the indicated times, aliquots were removed and centrifuged at 40,000 $\mathrm{g}$ in cell water tubes. The supernatant was separated and the packed cells hemolyzed with distilled water containing $10 \mu \mathrm{l}$ of Triton X-100. Both the supernatant and the hemolyzed cells were counted in a Packard gamma counter. (Packard Instrument Co. Inc., Downers Grove, Ill.). Hemoglobin in grams per deciliter was measured from the solubilized cells as cyanmethemoglobin complex at 540 OD. The influx was calculated from the ratio of cell counts to supernatant counts and expressed as millimoles $\mathrm{Na}$ per gram hemoglobin per hour. The trapped extracellular space was estimated from the counts in the hemolyzed cells of the " 0 time" sample.

To examine the effect of cetiedil on Ca-dependent $\mathrm{K}$ permeability, cells were washed in 10 vol of a $K$ wash containing, $\mathrm{KCl} 150 \mathrm{mM}$, Hepes $5 \mathrm{mM}$; pH 7.4 at $37^{\circ} \mathrm{C}$. Measurements of $\mathrm{Na}, \mathrm{K}$, and cell water were performed ("fresh" sample), following which ATP depletion was carried out by exposing cells for $60 \mathrm{~min}$ at $37^{\circ} \mathrm{C}$ to a solution containing, $\mathrm{KCl} 145 \mathrm{mM}$, Hepes $10 \mathrm{mM}$, inosine $10 \mathrm{mM}$, iodoacetate 1 $\mathrm{mM} ; \mathrm{pH}$ 7.4. The cells were again washed in the $\mathrm{K}$ wash to remove all traces of the inhibitor, and $\mathrm{Na}, \mathrm{K}$, and cell water measurements were done (" 0 time" sample). This repeated use of K-rich solutions prevented initiation of $\mathrm{K}$ loss during these preparative steps. The cells were then placed in $\mathrm{Na}$ rich solutions, the composition of which are indicated in the figure legends, and incubated at $37^{\circ} \mathrm{C}$. Aliquots of the suspension were removed at certain timepoints, washed with the $\mathrm{Na}$ wash, and processed for $\mathrm{Na}, \mathrm{K}$, and water content.

The cetiedil used in these studies was provided in powder form by Dr. Gérard Pilley of Innothéra Pharmaceuticals, Arcueil, France. It was suspended in a concentrated form in $95 \%$ ethanol and an identical volume of the vehicle was added to all control flasks.

Each experiment was carried out with both normal and sickle erythrocytes. Figs. 1, 2, 4, and 6 plot the mean and standard error of the mean of four identical experiments performed twice with normal erythrocytes and twice with sickle erythrocytes. The experiments illustrated in Figs. 3 and 5 were also repeated a minimum of four times. As these figures show doseresponse patterns, mean and standard error of the mean are not
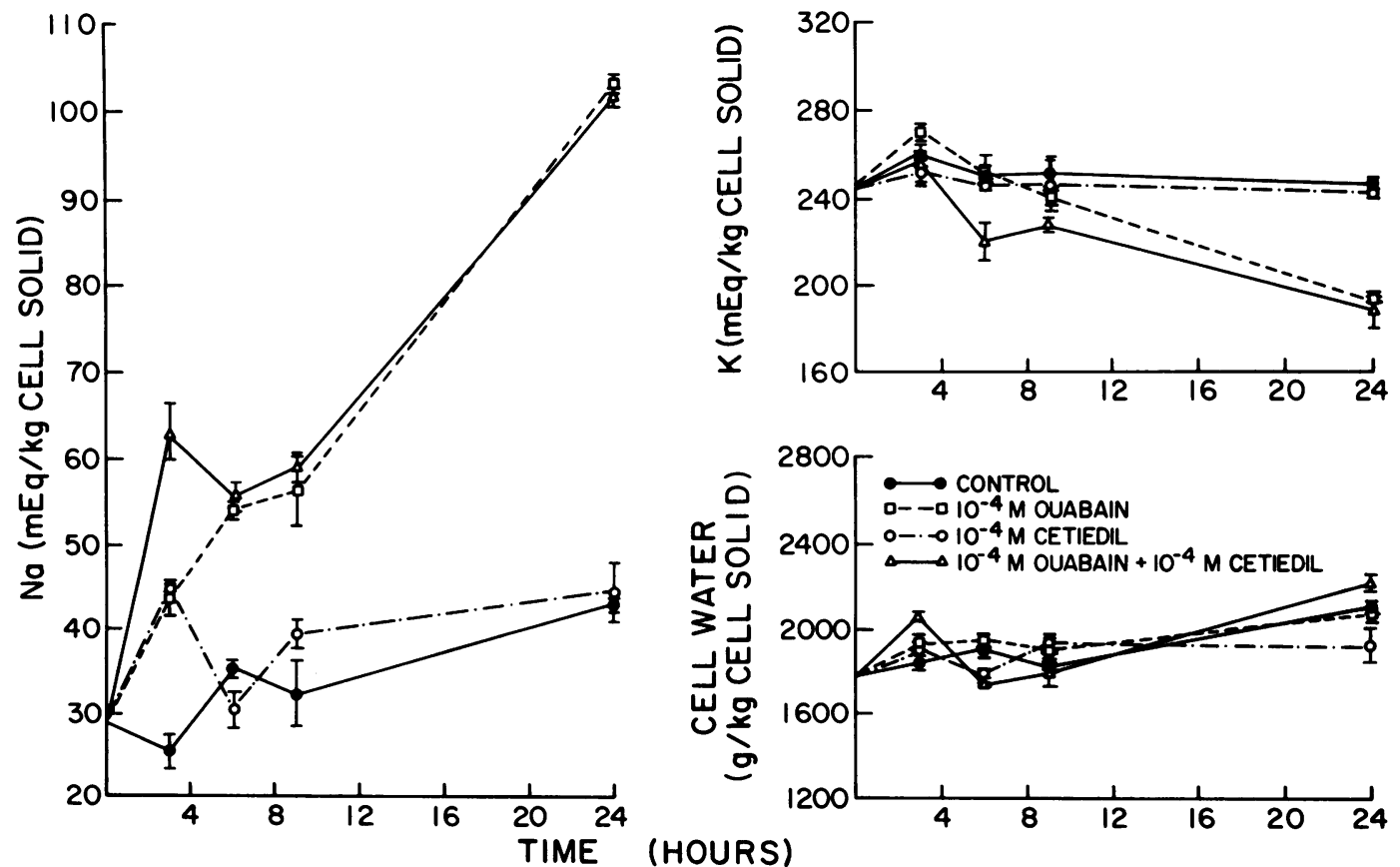

FIGURE 1 The effect of cetiedil $(0.1 \mathrm{mM})$ on ion and water content of erythrocytes during a 24-h incubation. Erythrocytes were divided into four flasks and incubated in a solution containing, $\mathrm{NaCl} 145 \mathrm{mM}$, KCl $5 \mathrm{mM}, \mathrm{Na}_{2} \mathrm{HPO}_{4} 2.5 \mathrm{mM}$, Hepes $10 \mathrm{mM}$, glucose $10 \mathrm{mM} ; \mathrm{pH} 7.5$ at $37^{\circ} \mathrm{C}$. Cetiedil $0.1 \mathrm{mM}$ and ouabain $0.1 \mathrm{mM}$ were added as indicated on the figure. 

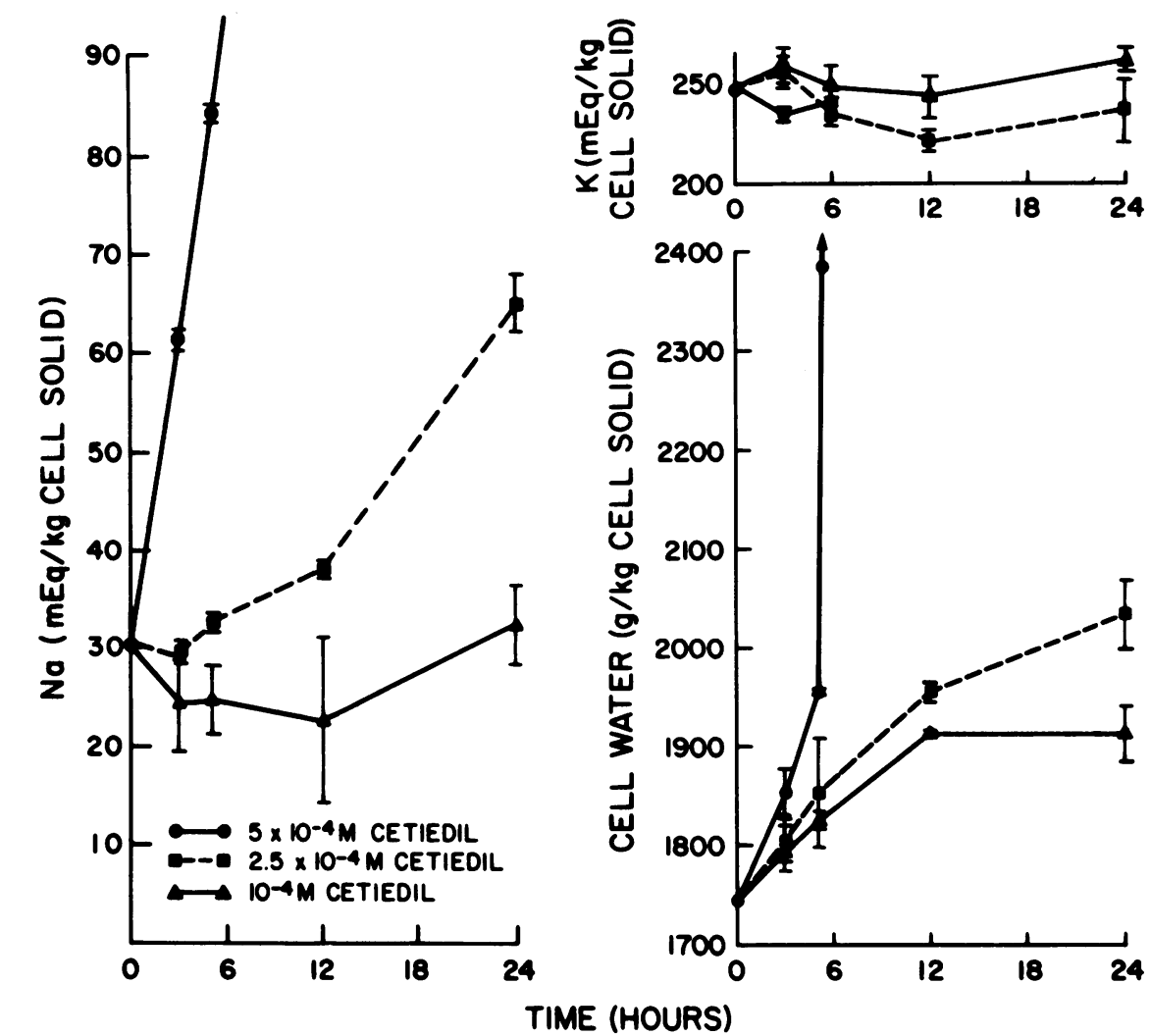

FIGURE 2 The effect of cetiedil $(0.1,0.25$ and $0.5 \mathrm{mM})$ on ion and water content of erythrocytes during a 24-h incubation. Erythrocytes were divided into three flasks and incubated in a solution containing, $\mathrm{NaCl} 145 \mathrm{mM}, \mathrm{KCl} 5 \mathrm{mM}, \mathrm{Na}_{2} \mathrm{HPO}_{4} 2.5 \mathrm{mM}$, Hepes $10 \mathrm{mM}$, glucose $10 \mathrm{mM} ; \mathrm{pH}$ 7.5 at $37^{\circ} \mathrm{C}$. Cetiedil was added to each flask at the indicated concentration.

shown. Each of these two figures is a representative doseresponse curve using sickle erythrocytes. The patterns of doseresponse achieved with normal erythrocytes were the same.

\section{RESULTS}

The effect of cetiedil on the ion and water content of erythrocytes during a 24-h net flux study is shown in Fig. 1. This experiment was performed in the presence and absence of ouabain. During the 24-h period, exposure to cetiedil alone at a concentration of $0.1 \mathrm{mM}$ caused no change in $\mathrm{Na}, \mathrm{K}$, or water content. Erythrocytes in a physiologic solution plus ouabain showed the expected gain of $\mathrm{Na}$ and loss of $\mathrm{K}$. Similar ion changes occurred when cetiedil was added to ouabain, but no additional effect was noted. At cetiedil concentrations above $0.1 \mathrm{mM}$, erythrocytes exhibited an increase in $\mathrm{Na}$ content even in the absence of ouabain (Fig. 2). At a cetiedil concentration of $0.5 \mathrm{mM}$, samples could only be obtained up to $6 \mathrm{~h}$ after which total hemolysis occurred, making longer incubations invalid.

To investigate further the etiology of the $\mathrm{Na}$ gain seen at higher concentrations of cetiedil, a ${ }^{22} \mathrm{Na}$ influx was performed. All samples were exposed to $0.1 \mathrm{mM}$ ouabain to eliminate active $\mathrm{Na}$ efflux via the $\mathrm{Na}-\mathrm{K}$ pump.
Concentrations of cetiedil identical to those in Fig. 2 $(0.1,0.25$, and $0.5 \mathrm{mM})$ were used. At $0.1 \mathrm{mM}$, the $\mathrm{Na}$ influx was identical to a control flask where no cetiedil was present. At cetiedil concentrations $>0.1$ $\mathrm{mM}, \mathrm{Na}$ influx was increased in a dose-dependent fashion (Fig. 3).

The next series of experiments was performed to evaluate the effect of cetiedil on erythrocyte $K$ permeability. Erythrocytes were exposed to in vitro conditions known to produce a selective increase in $\mathrm{K}$ permeability. ATP depletion was accomplished with inosine and iodoacetate. After 1-h exposure to the inhibitor, cell ATP levels were $<1 \%$. The erythrocytes were then placed into one of three Na solutions: $(a)$ a solution with EGTA, a Ca chelator; $(b)$ a solution with EGTA plus an excess of $\mathrm{Ca}$; or $(c)$ a solution with EGTA, an excess of $\mathrm{Ca}$, and cetiedil $0.1 \mathrm{mM}$. $\mathrm{Na}, \mathrm{K}$, and water content were measured at 30,60 , and $120 \mathrm{~min}$ (Fig. 4). Cells exposed to an excess of $\mathrm{Ca}$ showed marked $\mathrm{K}$ loss and cell dehydration, changes which were not observed if $\mathrm{Ca}$ was omitted from the incubation vessel. This Cadependent $\mathrm{K}$ and water loss was totally inhibited by cetiedil.

The dosage dependency of cetiedil on inhibition 


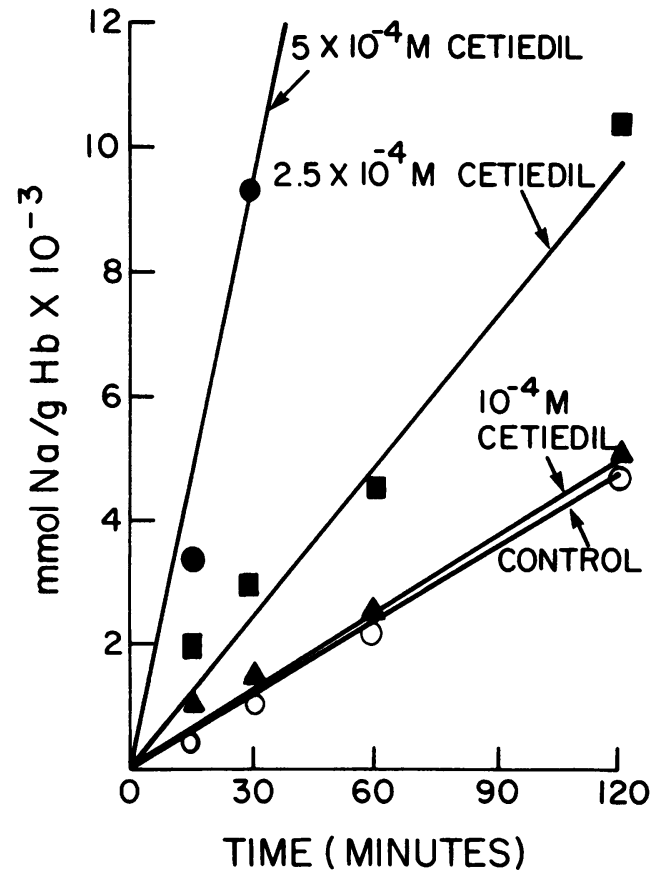

Figure 3 The effect of cetiedil on unidirectional $\mathrm{Na}$ influx in erythrocytes. Erythrocytes were divided into four flasks and incubated in a solution containing, $\mathrm{NaCl} 145 \mathrm{mM}, \mathrm{KCl} 5$ $\mathrm{mM}, \mathrm{Na}_{2} \mathrm{HPO}_{4} 2.5 \mathrm{mM}$, Hepes $10 \mathrm{mM}$, glucose $10 \mathrm{mM}$; pH 7.5 at $37^{\circ} \mathrm{C}$. Ouabain $0.1 \mathrm{mM}$ was present in all flasks. Cetiedil was added in the concentrations indicated. After a 5 min equilibration period, ${ }^{22} \mathrm{Na}$ was added and the rate of ${ }^{22} \mathrm{Na}$ influx was measured.

of $\mathrm{K}$ and water loss is seen in Fig. 5. Erythrocytes were ATP-depleted and exposed to graded concentrations of cetiedil from 0 to $0.1 \mathrm{mM}$. Ca was present
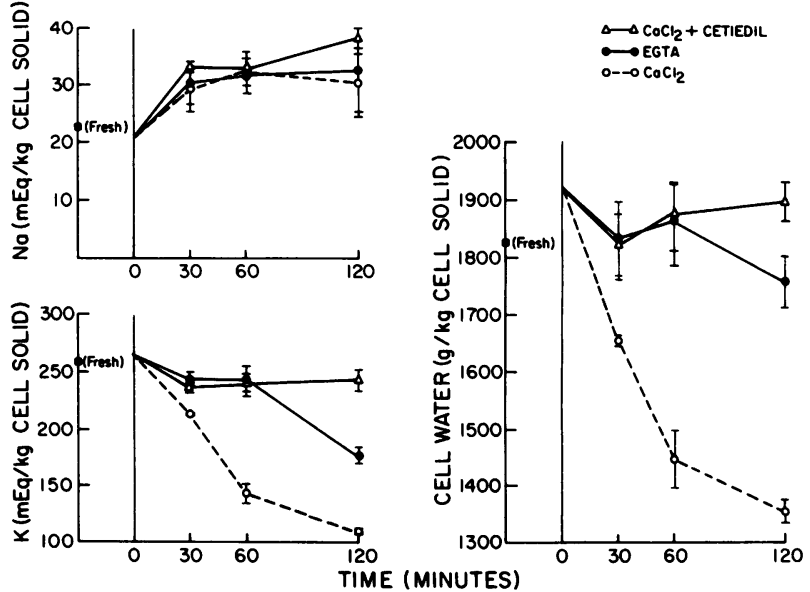

Figure 4 The effect of cetiedil on Ca-mediated $\mathrm{K}$ permeability in the erythrocyte. Erythrocytes were incubated for $1 \mathrm{~h}$ in a solution containing, $\mathrm{KCl} 145 \mathrm{mM}$, Hepes $10 \mathrm{mM}$, inosine $10 \mathrm{mM}$, iodoacetate $1 \mathrm{mM} ; \mathrm{pH} 7.5$ at $37^{\circ} \mathrm{C}$. The erythrocytes were then placed into one of three solutions as indicated on the figure: (1) $\mathrm{NaCl} 150 \mathrm{mM}$, Hepes $10 \mathrm{mM}$, EGTA $0.25 \mathrm{mM}$ (2) $\mathrm{NaCl} 150 \mathrm{mM}$, Hepes $10 \mathrm{mM}$, EGTA $0.25 \mathrm{mM}$, $\mathrm{CaCl}_{2} 2 \mathrm{mM}$; (3) $\mathrm{NaCl} 150 \mathrm{mM}$, Hepes $10 \mathrm{mM}$, EGTA $0.25 \mathrm{mM}$, $\mathrm{CaCl}_{2} 2 \mathrm{mM}$, cetiedil $0.1 \mathrm{mM}$.

in all solutions. A graded dose-response was seen with maximum inhibition of $\mathrm{K}$ and water loss at $0.1 \mathrm{mM}$ cetiedil. Little effect was seen at $10 \mu \mathrm{M}$ cetiedil.

The final experiment tested the ability of cetiedil to inhibit $\mathrm{K}$ and water loss once initiated (Fig. 6). After ATP depletion, all erythrocytes were placed for $60 \mathrm{~min}$ in a solution containing an excess of $\mathrm{Ca}$. At the end of this hour, $\mathrm{K}$ and water loss had begun. The cells were then divided into two flasks and cetiedil, at a concentra-
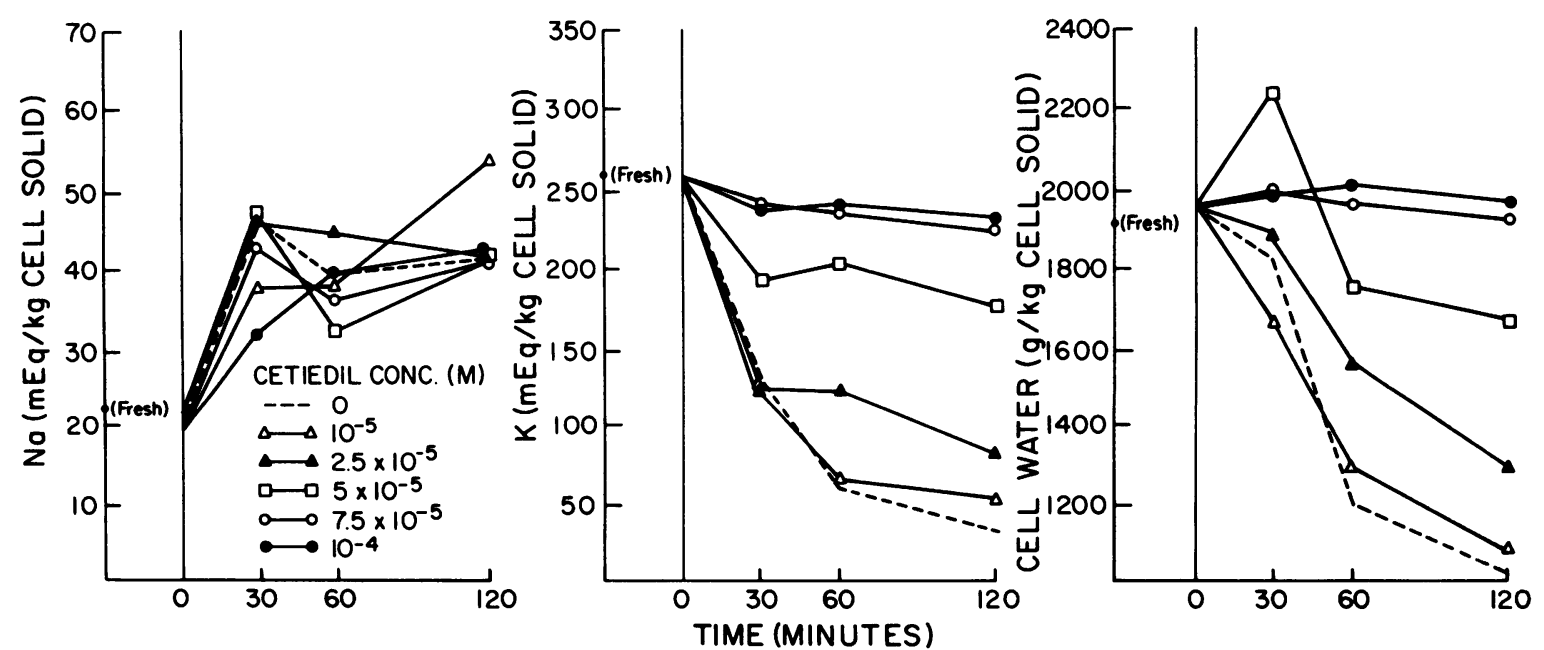

Figure 5 The dosage dependency of cetiedil on Ca-mediated $\mathrm{K}$ permeability in the erythrocyte. Erythrocytes were incubated for $1 \mathrm{~h}$ in a solution containing, KCL $145 \mathrm{mM}$, Hepes $10 \mathrm{mM}$, inosine $10 \mathrm{mM}$, iodoacetate $1 \mathrm{mM} ; \mathrm{pH} 7.5$ at $37^{\circ} \mathrm{C}$. The erythrocytes were then placed into six flasks in a solution containing, $\mathrm{NaCl} 150 \mathrm{mM}$, Hepes $10 \mathrm{mM}$, EGTA $0.25 \mathrm{mM}, \mathrm{CaCl}_{2} 2 \mathrm{mM}$; $\mathrm{pH}$ 7.5 at $37^{\circ} \mathrm{C}$. Cetiedil was added to each flask at the concentration indicated on the figure. 


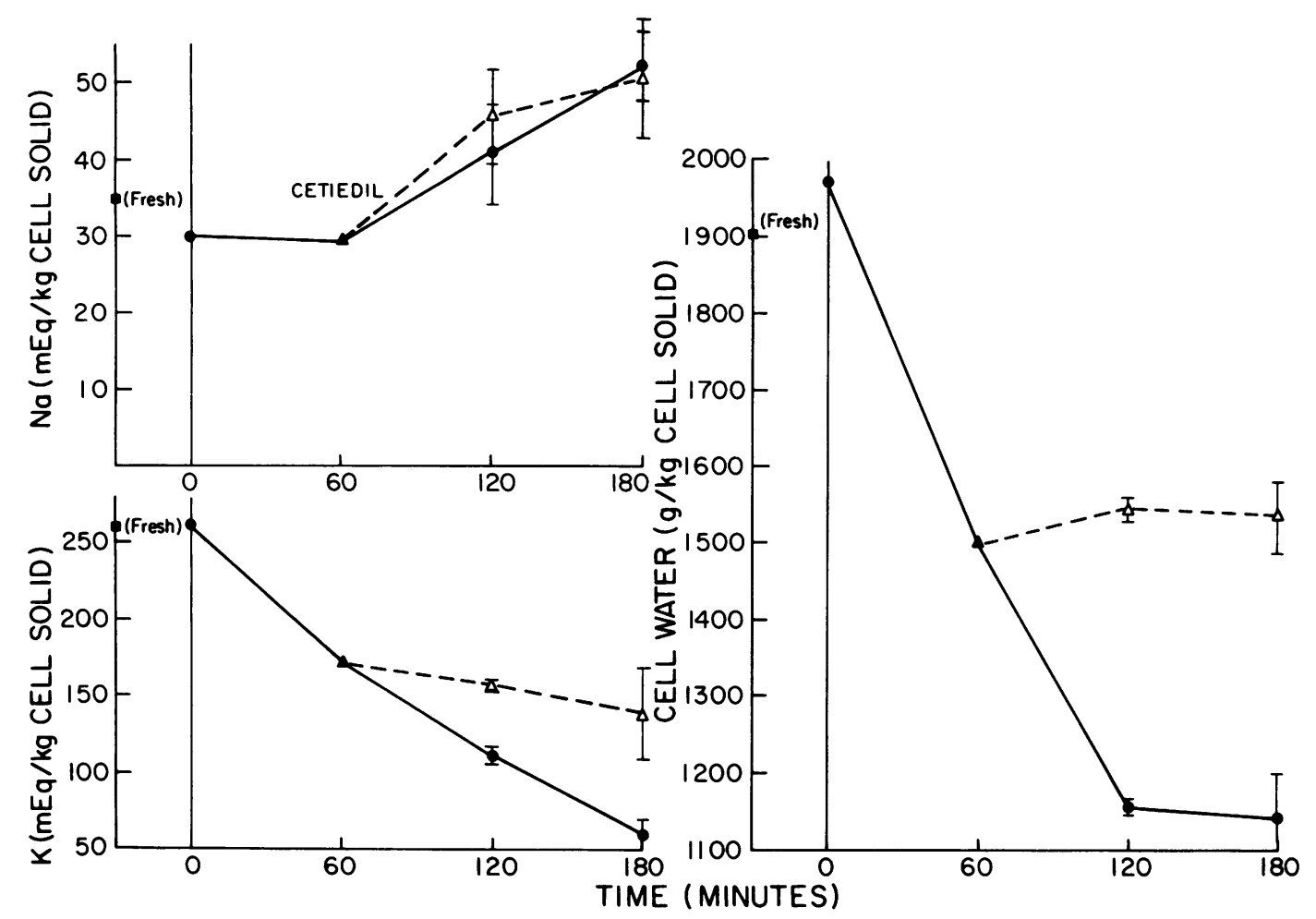

FIGURE 6 The effect of cetiedil on Ca-mediated $\mathrm{K}$ permeability, once initiated, in the erythrocyte. Erythrocytes were incubated for $1 \mathrm{~h}$ in a solution containing, $\mathrm{KCl} 145 \mathrm{mM}$, Hepes 10 $\mathrm{mM}$, inosine $10 \mathrm{mM}$, iodoacetate $1 \mathrm{mM} ; \mathrm{pH} 7.5$ at $37^{\circ} \mathrm{C}$. Erythrocytes were next incubated for $1 \mathrm{~h}$ in a solution containing, $\mathrm{NaCl} 150 \mathrm{mM}$, Hepes $10 \mathrm{mM}$, EGTA $0.25 \mathrm{mM}, \mathrm{CaCl}_{2} 2 \mathrm{mM}$. Erythrocytes were then divided into 2 flasks and $0.1 \mathrm{mM}$ cetiedil added to one flask (dashed line).

tion of $0.1 \mathrm{mM}$, was added to one. Those cells not exposed to cetiedil continued to lose $\mathrm{K}$ and water. Unlike the control flask, however, $\mathrm{K}$ loss and cell dehydration were abruptly terminated as soon as the erythrocytes were exposed to cetiedil.

\section{DISCUSSION}

The foregoing experiments suggest that cetiedil might exert its antisickling effect by preventing an increase in the concentration of cytoplasmic hemoglobin through an influence on erythrocyte ion and water content. Because the concentration of hemoglobin within all erythrocytes is the major determinant of cytoplasmic viscosity, a rise in hemoglobin concentration results in a fall in cell deformability (14). An increase in hemoglobin concentration exerts a second, particularly deleterious effect upon sickle erythrocytes. In these cells the rate at which hemoglobin $S$ aggregates following deoxygenation is enormously influenced by the cell hemoglobin concentration (5).

Since hemoglobin is an impermeant species, its intracellular concentration is determined by the water content of the erythrocyte, which in turn is a function of the number of osmotically active particles within the cell. Because $\mathrm{K}$ is the major intracellular cation, a permeability defect specific for $\mathrm{K}$ and not $\mathrm{Na}$ will result in the loss of cellular ions and water (15). Several lines of evidence suggest that the sickle erythrocyte becomes dehydrated during cycles of deoxygenation and that this loss of cell water with its resultant increase in cytoplasmic viscosity and impaired cellular deformability is the result of $\mathrm{K}$ loss $(6-9)$. The mechanism by which such an increase in $\mathrm{K}$ permeability might develop is less certain. An attractive hypothesis would suggest that repeated cycles of deoxygenation promote the intracellular accumulation of $\mathrm{Ca}$ ions $(16,17)$. A rise in the $\mathrm{Ca}$ content in the erythrocyte is known to cause $\mathrm{K}$ loss by creating $\mathrm{K}$-specific channels in the erythrocyte membrane $(12,18)$. Data supporting such a sequence of events in the sickle erythrocyte include the following: $(a)$ increased $\mathrm{Ca}$ content of the sickle erythrocyte $(17,19) ;(b)$ loss of $\mathrm{K}$ from sickle erythrocytes during deoxygenation (6); and (c) shrinkage of sickle erythrocytes upon deoxygenation. (9). One could easily envision as the end result of this process, the severely dehydrated, energy-depleted, irreversibly sickled cell $(8,20)$.

Unlike other antisickling agents, cetiedil does not appear to interact with hemoglobin $\mathrm{S}$ since oxygen 
affinity and solubility remain unchanged (3). The drug, however, exerts two distinct effects on monovalent cation permeability, each of which would tend to prevent cell dehydration. Either effect of cetiedil would inhibit the increase in cell hemoglobin concentration observed in sickle erythrocytes and thus preserve their intrinsic deformability. Such an hypothesis is consistent with the "swelling" noted by Asakura et al. (3).

It is reasonable to speculate that the mechanism of action of a potential antisickling agent involves a change in erythrocyte membrane permeability rather than a modification of the hemoglobin $\mathrm{S}$ molecule. Before assuming clinical relevance for these in vitro studies with cetiedil, however, a similar reduction in cell dehydration must be demonstrated in vivo. Controlled clinical trials, which include these in vivo measurements of erythrocyte cation and water content, will attempt to correlate physiologic effects on the sickle erythrocyte with amelioration of sickle cell crises.

\section{ACKNOWLEDGMENTS}

We are indebted to Dr. John C. Parker for his advice and helpful suggestions and to Fay Weaver for expert secretarial assistance.

Supported in part by National Institutes of Health grant AM11376.

\section{REFERENCES}

1. Benjamin, L. J., G. Kokkini, and C. M. Peterson. 1980. Cetiedil: its potential usefulness in sickle cell disease. Blood. 55: 265-270.

2. Cabannes, R. Preliminary study on the effects of cetiedil in acute episodes of sickle cell anemia. Presented at the International Symposium on Vascular Disease, February 1977, Rome, Italy.

3. Asakura, T., S. T. Ohnishi, K. Adachi, M. Oxcuc, K. Hashimoto, M. Singer, M. O. Russell, and E. Schwartz. 1980. Effect of cetiedil on erythrocyte sickling. New type of antisickling agent that may affect erythrocyte membranes. Proc. Natl. Acad. Sci.U.S. A. 77: 2955-2959.

4. Mohandas, N., W. M. Phillips, and M. Bessis. 1979. Red blood cell deformability and hemolytic anemias. Semin. Hematol. 16: 95-114.
5. Hofrichter, J., P. D. Ross, and W. A. Eaton. 1976. Supersaturation in sickle cell hemoglobin solutions. Proc. Natl. Acad. Sci. U. S. A. 73: 3035-3039.

6. Tosteson, D. C., E. Shea, and R. C. Darling. 1952. Potassium and sodium of red blood cells in sickle cell anemia. J. Clin. Invest. 31: 406-411.

7. Glader, B. E., and D. G. Nathan. 1978. Cation permeability alterations during sickling: relationship to cation composition and cellular hydration of irreversibly sickled cells. Blood. 51: 983-989.

8. Glader, B. E., S. E. Lux, A. Muller-Soyana, O. S. Platt, R. D. Propper, and D. G. Nathan. 1978. Energy reserve and cation composition of irreversibly sickled cells in vivo. Brit. J. Haematol. 40: 527-532.

9. Masys, D. R., P. A. Bromberg, and S. P. Balcerzak. 1974. Red cells shrink during sickling. Blood. 44: 885-889.

10. Zarkowsky, H. S., and R. M. Hochmuth. 1975. Sickling times of individual erythrocytes at zero $\mathrm{PO}_{2}$. J. Clin. Invest. 56: 1023-1034.

11. Rosa, R. M., B. E. Bierer, R. Thomas, J. S. Stoff, M. Kruskall, S. Robinson, H. F. Bunn, and F. H. Epstein. 1980. A study of induced hyponatremia in the prevention and treatment of sickle-cell crisis. N. Engl. J. Med. 303: 11381143.

12. Gardos, G. 1959. The role of calcium in the potassium permeability of human erythrocytes. Acta Physiol. Acad. Sci. Hung. 15: 121-125.

13. Parker, J. C., H. J. Gitelman, P. S. Glosson, and D. L. Leonard. 1975. Role of calcium in volume regulation by dog red blood cells. J. Gen. Physiol. 65: 84-96.

14. Mohandas, N., M. R. Clark, M. S. Jacobs, and S. B. Shohet. 1980. Analysis of factors regulating erythrocyte deformability. J. Clin. Invest. 66: 563-573.

15. Orringer, E. P., and J. C. Parker. 1973. Ion and water movements in red blood cells. In Progress in Hematology. E. B. Brown, editor. Grune \& Stratton, Inc., New York. 8: $1-23$.

16. Bookchin, R. M., and V. L. Lew. 1980. Progressive inhibition of the Ca pump and Ca:Ca exchange in sickle red cells. Nature (Lond.). 284: 561-563.

17. Eaton, J. W., T. D. Skelton, H. S. Swofford, C. E. Kolpin, and H. S. Jacob. 1973. Elevated erythrocyte calcium in sickle cell disease. Nature (Lond.). 246: 105-106.

18. Plishker, G., and H. J. Gitelman. 1976. Calcium transport in intact human erythrocytes. J. Gen. Physiol. 68: 29-41.

19. Palek, J. 1977. Red cell calcium content and transmembrane calcium movements in sickle cell anemia. J. Lab. Clin. Med. 89: 1365-1374.

20. Clark, M. R., N. Mohandas, and S. B. Shohet. 1980. Deformability of oxygenated irreversibly sickled cells. $J$. Clin. Invest. 65: 189-196. 